\title{
AN EMPIRICAL ANALYSIS OF PERFORMANCE IMPACTS RESULTING FROM CONVERSION TO FRANCHISE OPERATIONS
}

\author{
James Hesford \\ Ecole hoteliere de Lausanne \\ Mina Pizzini \\ Texas State University and the Naval Postgraduate School \\ Gordon Potter \\ Cornell University
}

Address correspondence to
Mina Pizzini
Email: wjp23@txstate.edu

December 30, 2014

Preliminary and Incomplete: Please Do Not Copy or Quote 


\title{
AN EMPIRICAL ANALYSIS OF PERFORMANCE IMPACTS RESULTING FROM CONVERSION TO FRANCHISE OPERATIONS
}

\begin{abstract}
Franchising is an important form of organizational control. Possible benefits of franchising include its ability to reduce agency costs that increase with costly monitoring, and provide incentives for the use of local information by onsite managers. However, these benefits may come at a cost, as franchisees may reduce quality by choosing to free ride. While many studies have investigated the reasons for franchising, few studies have documented the impacts of franchising on unit level operating performance. Using time-series data from a number of lodging properties that were converted to franchisee control from company control, this study documents the performance impacts of franchising. The analysis reveals that conversion results in a modest decline in financial performance and an immediate sharp decline in quality.
\end{abstract}

Key Words: control, organizational design, performance evaluation, franchise operations, hospitality industry.

Data availability: The confidentiality agreement with the firm that provided data for this study precludes revealing its identity and disseminating data without its written consent. 


\section{AN EMPIRICAL ANALYSIS OF PERFORMANCE IMPACTS RESULTING FROM CONVERSION TO FRANCHISE OPERATIONS}

\section{INTRODUCTION}

Determining the most effective set of management controls through delegation, incentives and performance measurement is a critical issue for accountants and managers alike. Franchising is recognized as an important form of organizational control (e.g. van der Meer-Koistra and Vossleman 2006; Lafontaine and Slade 2007; Campbell, Datar and Sandino 2009). Possible benefits

of franchising include its ability to reduce agency costs that increase with costly monitoring (Brickley and Dark 1987; Norton 1988), and provide incentives for the use of local information by onsite managers (Sorenson and Sorenson 2001, Raith 2008). However, these benefits can come at a cost, as franchisees may reduce quality by choosing to free ride on the franchisor's reputation (Brickley and Dark 1987) or in response to a possible hold up by the franchisor. While many studies have investigated the reasons for franchising, few studies have documented the impacts of franchising on unit level operating performance (Yin and Zajac 2004). Using time-series data from a number of lodging properties managed by a firm that converted to franchisee control from company control, this study provides empirical evidence on two research questions: (1) does conversion to franchisee control lead to improved financial (revenue) performance and (2) does conversion to franchises result in a reduction in quality. The analysis reveals that conversion results in a modest decline in revenue and a sharp decline in quality. Both performance impacts are immediate.

Agency problems impact the choice of organizational form. From an agency perspective, firms design the location of decision making around the quality of contractible performance measures (Milgrom and Roberts 1992, Prendergast 2002, Moers, 2006). The choice of organizational control in large multi-outlet firms is complex as these companies tend to have 
multiple units spread over a wide geographic area. These units are expected to provide a common good or service using a similar technology (Brickley and Dark, 1987). Because the cost of search for goods and services by transient customers is high (Caves and Murphy, 1976), unit level uniformity is critical.

Franchising is one organizational form of control that is used extensively by multi-unit firms. Brickley and Dark (1987), Norton (1988) and LaFontaine (1992) suggest that franchising can help reduce the costs of monitoring units by providing financial incentives to the local managers in the form of residual claims. Since the typical franchise contract puts all the weight on output realizations, it should also help induce local operators to use their specific knowledge (Raith 2008). Moreover, if there is a lot of geographical dispersion across a firm's markets, franchising can also promote innovation and solutions to local problems and merchandise mix (Bradach 1997, Sorenson and Sorensen 2001, Campbell, Datar and Sandino 2009). These benefits suggest that units that are franchised should result in improved performance. However, franchisees incur an externality when there are few repeat customers because they incur the full cost of investment, but only realize part of the benefits. Therefore, they have an incentive to reduce the quality of the good or service provided (Caves and Murphy 1978). Provided information on quality is discernable by customers, any deterioration in quality may dampen any performance gains.

In this study we use lengthy time-series data from 56 lodging properties owned and operated by one firm that company converted to franchisee control sequentially over a six-year period. We examined the properties relative revenue performance by comparing the properties' revenue, and well as price and quantities, to those of their competitors. We find that although prices increase upon conversion, total revenue and quantity sold decline. Moreover, there is an immediate drop in 
quality upon conversion to a franchised unit that persists through the study period. Thus we find little performance improvement over a two-year period subsequent to conversion.

The remainder of this paper is structured as follows. Section 2 discusses the literature and develops the research hypotheses. Section 3 describes the research site, outlines the econometric model and presents the empirical results. Section 4 offers concluding remarks.

\section{HYPOTHESIS DEVELOPMENT}

\section{Franchising versus Ownership of Units}

There have been a number of academic studies on the determinants of franchising as an organizational form. After examining the franchising arrangement of 36 firms that contain some franchise units, Brickley and Dark (1987) find that the incidence of franchising increases with the distance a unit is from headquarters. Moreover, they find franchise units tend to be in less populated areas. They subscribe these results to the notion that monitoring costs are high in remote areas and thus franchising helps mitigate moral hazard problems. Norton (1988) investigates the incidence of franchising in the restaurant and hotel industries using 126 observations that measure the proportion of franchising in these industries in a particular state. Key findings are that franchising increases in rural areas, and for the hotel industry, with the extent of travel in the state. The study also documents that franchising increases with labor intensity, the size of the average outlet and the variability of customer demand. These economic drivers complement research in accounting that finds delegation of decision rights increases with size and uncertainty (Anderson, Glenn, Sedatole AOS 2000; Ittner, Larcker, Nagar, Rajan JAPP 1999?). 
Franchising can also aid organizations with innovation and uniformity problems. Bradach (1997) reports on a field study examining the structure of five restaurant chains. His inquiry concerned the organizational structure of the chains to facilitate uniformity and adaptability. He noted that a plural operating system, defined as a system in which the firm is operating both company-run and franchised units, was the approach used to solve the uniformity and adaptability issues. Company-owned units operated as a hierarchy with control over activities using budgets, internal promotions and corporate building, thus driving uniformity. Franchised units operated on a more local level using on-site experience and monetary incentives to promote adaptability. Franchise type arrangements can also arise to induce local managers to use their specific knowledge efficiently. Raith (2008) presents a model where even if agent effort is observable, it is still beneficial to pay the agent on output to induce the manager to use her effort effectively. Campbell, Datar and Sandino (2010) find argue that franchising might help attract local entrepreneurs who have a good sense of local conditions and have the flexibility to respond to local market dynamics. These authors document that the use of franchising is positively related to the degree of market dispersion.

While the benefits of franchising are clear, franchisees have an incentive to reduce the quality of the good or service provided (Caves and Murphy 1978, Lafontaine and Slade 2007). Provided information on quality is discernable by customers, any deterioration in quality may dampen any performance gains. Brickley and Dark (1987) conjecture that because a non-repeat customer base provides the franchisee with a greater incentive to free ride on the brand, industries with few repeat customers will be less likely to franchise. They find that hospitality related firms, which they define as firms with fewer repeat customers, have a lower proportion of 
franchised units than the other franchisers in their sample. However, research on the relation between franchising and repeat business is mixed (Lafontaine and Slade 2007).

\section{Performance Impacts of Franchising}

The organizational design literature discussed above suggests that the franchise contract can improve the performance of operating units by incentivizing the franchisee to work harder and to use his local knowledge to quickly respond to market conditions. Conversely, the franchisee may choose to free ride on the company's brand and forego the investment and effort necessary to maintain the brand's quality standards. While several studies have examined factors influencing the decision to franchise, relatively few have addressed unit-level performance effects of franchising.

\section{Revenues}

Two prior studies investigate the impact of franchising on revenues and/or profits. An early study by Shelton (1967) examined a sample of 22 restaurant outlets of a chain that had operated as both company-managed and as franchisee-managed restaurants. During the study period there were nine conversions from company-managed to franchisee-managed units and 22 conversions from franchisee control to owner control. Shelton found that revenues and profits were higher in periods of franchisee control than in periods of company control. He attributed these findings to the fact that franchisees "just watch the little things closer". ${ }^{\text {Conversely, Yin }}$ and Zajac (2004) do not find clear support for the financial benefits of franchising. They examined sales growth over a seven-year period using 23,400 year/outlet observations for a pizza company and found that company-owned properties had higher sales growth than franchised

\footnotetext{
${ }^{1}$ Some restaurants had multiple conversions and thus the number of conversions, 31, exceeds the number of outlets. Shelton examined changes in sales, profits and profits margins and found that all of these metrics were on average higher during franchisee control. Most pertinent to the current study are the nine conversions from company control to franchisee control. Upon conversion, six (67\%) resulted in higher sales, and seven (78\%) in higher profits and profit margins.
} 
units. However, if operating units employed a complex strategy, defined as both dine-in and delivery service, franchised units exhibited more sales growth. This suggests performance impacts may be contingent.

In our study, financial impacts are limited to the revenue impacts of franchising. These would come from the effectiveness of the franchise contract to induce operating managers to utilize their effort and their specific information to enhance sales productivity. Therefore, we test the following hypothesis:

\section{H1: Conversion of owned properties to franchised units results in an improvement in a property's revenues.}

Improvements in revenues arise from increases in price and/or units sold. The one area where results seem consistent is the impact of franchising on prices. Research on prices has generally found that franchisees have slightly higher prices that those found at company owned properties (Lafontaine and Slade 1997). For instance, Shepard (1993) found some evidence of higher prices at gasoline outlets that were less vertically integrated. Lafontaine (1999) found that prices at restaurants were higher in franchised rather than owned units, and that price dispersion also was larger at franchised units. Similar price differentials at restaurant were noted by Thomadsen (2005). Regarding higher prices, Lafontaine (1999) concluded that while franchisees bear the full cost of low prices, they do not gain all the demand generated by them because some customers go to other outlets. Price dispersion arises because the franchisor cannot control the prices of franchisees as well as it can control the prices of company-owned units. Therefore, we test the following hypotheses:

H1a: Conversion of owned properties to franchised units results in an increase in a property's prices. 
We are not aware of any studies that investigate the influence of franchising on the volume of units sold. As discussed previously, research indicates franchising does lead to higher prices, but it isn't clear whether franchising is associated with greater revenues. Ceteris paribus, higher prices will result in lower demand. Moreover, whereas the franchisor prefers to maximize royalties through unit sales, the franchisee prefers to improve profitability by trading price for quantity. Increasing the number of rooms sold increases operating costs and requires additional effort on the part of the franchisee, while increasing prices does not. Accordingly, we predict that occupancy will be lower after a property is converted to a franchised unit.

\section{H1b: Conversion of owned properties to franchised units results in a decrease in a property's unit sales.}

\section{Quality}

Franchisees may free ride on the company's brand rather than make expenditures and investments necessary to preserve service and property quality. For example, Kreuger (1991) finds that compensation at fast food restaurants is lower in franchised units than in companyowned units. This suggests that franchisees may attempt to reduce expenses by hiring lower ability workers, which potentially affects service quality. ${ }^{2}$ The incentive to reduce the quality of goods and services is most significant when there are few repeat customers because franchisees pay for the full investment in quality but only realize part of the benefits when customers go to other outlets (Caves and Murphy 1978, Brickley and Dark 1987). Other than the studies noted above on the relationship between repeat customers and franchising, there has been little work on this dimension of franchising. Michael (2000) provides some evidence by examining quality at the firm level, using 35 restaurants and 42 hotels, in cross-sectional analyses. His observations

\footnotetext{
${ }^{2}$ Alternatively, it may indicate that franchisees monitor their employees much more closely than managers in company-owned units, and therefore, do not need to compensate them as well.
} 
are not completely independent because some of the brands used in the study are owned by same firm. However, he found in both industries that the perceived quality of the brand decreased with the percentage of units franchised. He also found that, in the restaurant sample alone, perceived quality decreased with the number of units and the brand's growth rate but not geographic dispersion.

The conjecture that repeat business affects quality is predicated on the assumption that customers base their purchase decisions primarily on their prior experiences with the company. With the abundance of product and service reviews now available online, this may no longer be the case. Research in the hotel industry suggests that travelers make extensive use of online websites, such as Yahoo Travel, TripAdvisor and Expedia, when selecting a hotel room (e.g., Gretzel and Yoo 2008; Ye et al. 2009; Ong 2012; Melian-Gonzalez et. al. 2013). According to Gretzel and Yoo (2008), travel reviews influence half of all travelers' hotel purchase decisions. The wide dissemination of hotel reviews increases the likelihood that poor quality will adversely affect a franchisee's property, even if he has few repeat customers. Still, not all travelers consult websites before booking. Relatively few of the bookings for the hotels in our sample are made online, and almost half of the room purchases are made in cash, suggesting that many of the travelers in our sample may not consult online reviews before booking. Accordingly, we expect that quality will fall after company-owned properties are converted to franchise ownership, as stated in $\mathrm{H} 2$.

\section{H2: Conversion of owned properties to franchised units results in a decrease in a property's quality.}

In summary, while the impact of prices seems clear from the prior literature, little is known about other performance effects. Shifting from low incentives to high power incentives 
should result in improved financial performance. In addition, self-selection effects that may come from local information about the demand from customers and sources of inputs should also lead to improved performance. However, underinvestment by the franchisee could result in lower quality and hence declining performance. Below we document these impacts for one chain in the lodging industry.

\section{EMPIRICAL DESIGN and RESULTS}

\section{Description of Site and Property Conversion Plan}

Our research site consists of a major economy lodging chain, such as Super 8, Red Roof, Motel 6 or Days Inn. The company owns or franchises far more than 500 properties, with the majority located in the United States. In this study the primary focus is the conversion of 56 lodging properties from company-owned and operated units to franchised units during the period 2006 through 2011. Firms in the hotel industry, like the restaurant and retail industries, continuously acquire and divest properties in their investment portfolio to reflect changes in local markets (changing customer demographics, regulation, competition, etc.). The company, during the period over which we had data, sold numerous properties. Some of these properties became franchise locations (i.e., continue to be affiliated with the brand) whereas others become independent hotels (i.e., a process known as "de-flagging"). For the current study we required each property to have a minimum of twelve months of observations before and after the asset sale. Of the initial data set of properties sold as franchises, three were dropped for insufficient data prior to the sale and about 40 were dropped because of insufficient data after the sale. We were missing data on competitors for 3 properties, resulting in the final data set of 56 properties.

Over a six-year period the firm sequentially converted 56 units owned and operated properties to franchises. Sequential conversion occurred because the plan required both the use 
of corporate resources, and the ability to find and train a qualified franchisee. For instance, with respect to corporate resources, brand compliance training needed to be started before the franchise opening. Moreover, corporate provided human resource training and sent a team to the opening. Finally, an "operation consistency" review was required after about 90 days. This sequential conversion helps control for time period effects.

The typical franchise contract for these converted units was for 15 years. Initial franchise fees ranged from $\$ 25,000$ to $\$ 35,000$ depending on room count. Once operating, there was an ongoing royalty fee amounting to $4.5 \%$ of gross revenues. In addition, there is also a $3.5 \%$ fee based on gross revenues for marketing and reservation center. Under this franchise agreement properties are not charged specific fees for reservations, so the $3.5 \%$ is charged regardless of usage resource usage. After conversion, the chain monitors the franchised unit by sending a franchise operating director to each property one or two times a year. This individual inspects the property and assesses brand compliance. Moreover, the company monitors the unit's state sales tax report and is permitted on the property at any time for revenue audits and for quality/brand compliance inspections.

\section{Data Collection}

Data were collected for the 56 properties that were converted to franchised units during the period January 2006 to April 2011. For purposes of analysis monthly data were obtained for a period of 49 months, starting 24 months prior to conversion and ending 24 months after conversion. $^{3}$ Revenue, room rates and occupancy data for the individual properties were electronically collected from the general ledgers maintained at corporate headquarters. Nonfinancial

\footnotetext{
${ }^{3}$ The minimum number of monthly observations for a property included in the final sample is 28 , and the mean number of observations per property is 46.39 . For a four year period centered on the conversion date, 46 of the 56 units had a complete set of 49 observations. Most lost observations occur because of the end cutoff date of May, 2012. As discussed later, we also obtained information for an additional 12 months for some of the converted units.
} 
information on monthly complaints at the property were also collected electronically. Company documents and interviews with senior managers and corporate staff provided qualitative data on their beliefs and expectations about the conversion program. In addition, general managers of multiple properties were interviewed to understand hotel operations.

\section{Financial and Nonfinancial Operating Measures}

The company only has access to detailed financial information on revenues for its franchised units. Each property's revenue is measured and reported using a uniform system of accounts for the lodging industry (Hotel Association of New York, Inc. 2006). Individual property revenue is a key financial measure considered in our analysis. Revenue per available room (REVENUE) is a widely used benchmark in the lodging industry. This measure can be partitioned multiplicatively into a rate (price) component, average rate (AVGRATE), measured as revenues divided by the number of occupied rooms, and a volume component, occupancy rate (OCCRATE), measured as the number of occupied rooms divided by the number of available rooms. Availability of data on available and occupied rooms of all individual units enables the use of these component measures in our analysis. To control for geographic and seasonal differences, for each property we were also provided by the chain with revenue information on its competitive set. Similar to most lodging organizations, the chain compares its unit's revenue performance relative to the property's local competition. These competitive set measures are computed by an independent agency that collects the relevant confidential information from participating hotels. With this information, for each month we were able to construct monthly competitor measures for revenue per room (COMPREV), average rate (CAVGRATE), and occupancy (COCCRATE).

A monthly customer complaints variable (COMPLNTS) is measured as the number of customer complaints per thousand occupied rooms. The number of customer complaints can be 
viewed as a measure of customer satisfaction and has been found to be negatively related to future financial performance (Banker, Potter, Srinivasan, 2000). Billing errors, service catastrophes and problems with service personnel are some of the prime reasons for customer switching behavior (Keaveney 1995). Analogous to defect rates in a manufacturing setting, customer complaints provide direct feedback on the hotel's operating processes and are useful for taking corrective actions. Customer complaints can also be viewed as an internal business process measure (Kaplan and Norton 1996; Ittner and Larcker 1998) that reflects the effectiveness of the operations at a hotel. Customers register their complaints either by calling the customer service center directly or by writing, and hence this measure cannot be manipulated easily.

\section{Preliminaries}

Table 1 documents the timing of the property conversion over the six-year period. The average property has about 102 rooms and annual revenue approximating $\$ 750,000$. While similar to the most of the chains properties in room count, revenue is lower than the average unit. This is indicative of a franchise conversion program that converted under-performing assets.

\section{Insert table 1 here}

Monthly operating data for the 56 converted hotels are presented in Table 2. The overall dispersions shown in Table 2 reflect seasonal variations and their geographic locations. Revenues per available room (REVENUE) for individual hotels vary considerably over the 12 months. Revenues per available room in the peak months can exceed the revenues per available room in the lean months of a year for individual hotels by a considerable margin. Competitors' revenues per available room (COMPREV) exhibit patterns similar to those of the revenue measure of the sample hotels, although competitor room rates (CAVGRATE) appear higher than the rates (AVGRATE) of the converted units. 
COMPREV is computed by an independent agency that collects the relevant confidential information from participating hotels. Prior industry and academic work indicates that COMPREV measure is a useful control for regional factors and some seasonality that affect revenues COMPLNTS for the entire converted sample average about one per thousand room nights. There is no complaint information for the competitive set.

\section{Insert table 2 here}

\section{Impact of Property Conversions on Operating Performance}

Our first research question focuses on the performance impacts of converting units from company owned and operated to franchises. Intuitively, one expects improvements in financial performance when it is more closely linked monetary incentives. In the economics literature this may occur as the local operator is now more directly rewarded for performance improvements. With nonfinancial performance, however, it not clear how local control will impact performance. Since franchisee's can free ride on the chain's reputation, they have incentive to reduce quality, resulting in an increase in customer complaints. However, this will be mitigated by the potential for repeat business and other reputation effects on long term performance.

Estimating the initial effects of franchise conversion involves assessing the impact of the change on key operating metrics. As described above, we obtained monthly operating measures on revenues and complaints for up 24 months prior to, and up to 24 months subsequent to, the month of conversion. ${ }^{4}$ To estimate the conversion's effect on performance we specify the following model of revenue components, and alternatively complaints, in month $t, t=1, \ldots, 49$, of each property $i, i=1, \ldots, 56$, as:

AVGRATE $_{\text {it }} \quad=\alpha_{0}{ }^{\mathrm{A}}+\sum_{\mathrm{i}=1}^{55} \beta_{\mathrm{i}}^{\mathrm{A}}$ PROPERTY $_{\mathrm{i}}+\sum_{\mathrm{i}=1}^{56} \gamma_{\mathrm{i}}^{\mathrm{A}}$ PROPERTY $_{\mathrm{i}}$ CAVGRATE $_{\mathrm{it}}+\sum_{\mathrm{q}=2}^{4} \gamma_{\mathrm{q}}{ }^{\mathrm{A}} \mathrm{D}_{\mathrm{q}}$

\footnotetext{
${ }^{4}$ Recall we have on average slightly more than 46 observations per property. A complete sample would include 49 observations per property.
} 


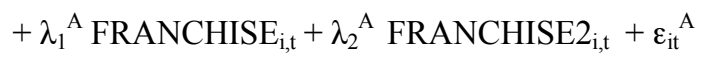

$$
\begin{aligned}
& \text { OCCRATE }_{\mathrm{it}}=\alpha_{0}{ }^{\mathrm{O}}+\sum_{\mathrm{i}=1}^{55} \beta_{\mathrm{i}}^{\mathrm{O}} \text { PROPERTY }_{\mathrm{i}}+\sum_{\mathrm{i}=1}^{56} \gamma_{\mathrm{i}}^{\mathrm{O}} \text { PROPERTY }_{\mathrm{i}} \text { COCCRATE }_{\mathrm{it}}+\sum_{\mathrm{q}=2}^{4} \gamma_{\mathrm{q}}^{\mathrm{o}} \mathrm{D}_{\mathrm{q}}
\end{aligned}
$$

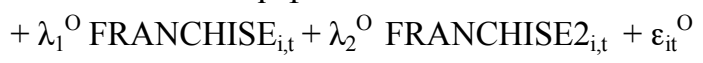

$$
\begin{aligned}
& \text { REVENUE }_{i t} \quad=\alpha_{0}{ }^{\mathrm{R}}+\sum_{\mathrm{i}=1}^{55} \beta_{\mathrm{i}}^{\mathrm{R}} \text { PROPERTY }_{\mathrm{i}}+\sum_{\mathrm{i}=1}^{56} \gamma_{\mathrm{i}}^{\mathrm{R}} \text { PROPERTY }_{\mathrm{i}} \mathrm{COMPREV}_{\mathrm{it}}+\sum_{\mathrm{q}=2}^{4} \gamma_{\mathrm{q}}{ }^{\mathrm{R}} \mathrm{D}_{\mathrm{q}} \\
& +\lambda_{1}{ }^{\mathrm{R}} \text { FRANCHISE }_{\mathrm{i}, \mathrm{t}}+\lambda_{2}{ }^{\mathrm{R}} \text { FRANCHISE } 2_{\mathrm{i}, \mathrm{t}}+\varepsilon_{\mathrm{it}}^{\mathrm{R}} \\
& \text { COMPLNTS }_{\text {it }} \quad=\alpha_{0}{ }^{\mathrm{C}}+\sum_{\mathrm{i}=1}^{55} \beta_{\mathrm{i}}{ }^{\mathrm{C}} \text { PROPERTY }_{\mathrm{i}}+\sum_{\mathrm{i}=1}^{56} \gamma_{\mathrm{i}}^{\mathrm{C}} \text { PROPERTY }_{\mathrm{i}} \text { CCOMPLNTS }_{\mathrm{it}}+\sum_{\mathrm{q}=2}^{4} \gamma_{\mathrm{q}}{ }^{\mathrm{C}} \mathrm{D}_{\mathrm{q}}
\end{aligned}
$$

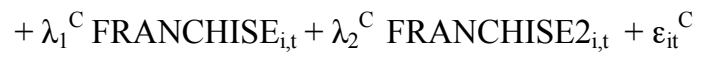

where,

PROPERTY $_{\mathrm{i}}=\mathrm{A}_{\text {dummy variable }}=1$ if PROPERTY $\mathrm{i}$, otherwise zero,

$\mathrm{D}_{\mathrm{q}} \quad=$ Indicator variable for quarters $\mathrm{q}$,

FRANCHISE = indicator variable that equals one upon conversion, otherwise zero,

FRANCHISE2 = indicator variable that equals one 12 months after conversion, otherwise zero,

REVENUE = Revenue per available room of a property,

AVGRATE $=$ Average rate for a property measured as total revenues divided by number of occupied rooms in a month,

OCCRATE = Occupancy rate for a property measured as number of occupied rooms divided by number of available rooms in a month,

COMPLNTS = Number of complaints per thousand guests for a property in a month,

COMPREV = Average revenue per available room of competitors of a property in a month,

CAVGRATE = Average rate of competitors of a property in a month,

COCCRATE = Average occupancy rate of competitors of a property in a month.

CCOMPLNTS = monthly average complaints per thousand rooms for company's owned properties.

The above models specify revenue per available room and its components as functions of exogenous parameters, seasonal effects, and conversion impacts. The exogenous variables that affect financial performance in the lodging industry include hotel-specific factors, seasonality, local, regional and other economy-wide factors like inflation (Banker et al. 2000). Therefore, to control for specific characteristics of individual hotels that may result in correlated residuals over time, we include intercept dummies for individual hotels in these fixed-effects models (Greene 1994). To control for other exogenous factors that affect revenues, we include an index (labeled COMPREV) measuring the average revenues per available room of competitors in the same location as the hotel. This measure (COMPREV) is the most widely used benchmark in the hotel industry and best 
captures the exogenous shocks that affect revenues such as seasonality and inflation experienced by the local hotel industry. We test for the hypothesized effects of the franchise conversion by examining the intercept shift coefficients, $\lambda_{1}$ and $\lambda_{2}$. A positive (negative) $\lambda_{1}$ is interpreted as the conversion having a positive (negative) effect on sales over the test period of 24 months. A positive (negative) $\lambda_{2}$ is interpreted as the conversion having an incremental positive (negative) effect on revenue sales beginning 12 months after conversion.

We control for serial correlation in our time-series data by using a variant of the PraisWinsten (1954) estimator proposed by Park and Mitchell (1980). We do not expect to find heteroscedasticity, as dividing each financial variable by number of square feet controls for differences in store size. We also examined an alternative estimation model (not reported) to verify the robustness of our results to model specifications.

\section{Estimation of Impacts}

Table 3 present plots of the average standardized residuals for the 56 stores that converted to franchise units. The residuals are centered on the month of conversion (event time $=$ 0 ). The residuals for each of the 56 properties are computed as prediction errors from the following model:

$$
\text { REVENUE }_{i t}=\alpha_{i}+\beta_{\mathrm{s}} \text { COMPREV }_{i t}+\varepsilon_{i}
$$

The parameters, $\alpha_{\mathrm{s}}$ and $\beta_{\mathrm{s}}$, are estimated using the 24 monthly observations prior to the unit's conversion. The residuals are standardized by scaling by the square root of the model's mean squared errors. In addition to REVENUE, models are built to estimate prediction errors for AVGRATE, OCCRATE and COMPLNTS using as predictors CAVGRATE, COCCRATE, and CCOMPLNTS, respectively. 


\section{Insert table 3 here}

Figure 1 reveals a small drop in revenue per room (REVENUE) that begins slightly before conversion and seems to persist throughout the period. Figure 2 depicts unexpected room rates (AVGRATE) upon conversion. There appears to be a sharp increase in rates starting at the conversion date. Moreover, the rate increases seem to expand during the study period. Figure 3 reveals that occupancy begins to drop a few months before conversion, and falls further during the study period. Finally, Figure 4 reveals a rather large increase in complaints that occur right at conversion that continue over the following 24 months. However, there appears to be a slight reduction in the magnitude of complaints increase after 12 months.

\section{Insert table 4 here}

Our point estimates of conversion impacts are presented in Table 4. The figures above suggested some additional seasonality and this in part motives control for quarterly effects in the estimated models. Importantly, all models are significant and are generally supportive of the conversion impacts suggested above in the figures. Looking at the AVGRATE impacts, the FRANCHISE coefficient confirms that the conversion resulted in a $\$ 2.23$ increase in room rates. Moreover, the coefficient on FRANCHISE2 reveals that rates increased, on average, another $\$ 0.43$ after 12 months, resulting in a total rate increase of $\$ 2.66$ after one year $(p=.0001)$. OCCRATE drops significantly upon conversion and persist over the entire franchise period. However, the entire impact occurs in the first year after conversion, as FRANCHISE2 is not significant. Given these findings, it is not surprising that revenue per room, REVENUE, drop about $\$ 0.86$ per room per night upon conversion. Moreover, the loss in revenue persists over the entire franchise period. Finally, COMPLNTS increase about 0.38 at conversion. However, one year out, although significantly higher than expected $(\mathrm{p}=0.001)$, COMPLNTS have dropped down to an increase of $0.172(=0.384-0.212)$. Overall, conversion of properties to franchised 
units has resulted significant reductions in revenue and nonfinancial performance, despite of increasing prices. ${ }^{5}$

\section{CONCLUSION}

While there has been much work on the determinants of franchising as a form of organizational control, there has been little work on the performance impacts of franchising (Yin and Zajac 2004). In this study we use lengthy time-series data from 56 of lodging properties owned and operated by one firm that the company converted to franchisee control over a six year period. We examined the properties relative revenue performance by comparing the properties' revenue, and well as price and quantities, to those of their competitors. We find that although prices increase immediately upon conversion, total revenue and quantity sold decline. This is despite a relatively large and persistent price increase. Moreover, there is an immediate and persistent drop in quality upon conversion to a franchised unit. Thus we find little performance improvement over a two year period subsequent to conversion.

The paper does have some limitations that may be resolved with future research. One limitation of our study is that it is possible that although revenue and quality dropped, the price increases and expense cutbacks resulted in improved profitability. Our study does not have expense information after conversion so we are unable to answer this question. However, it is very unlikely the tradeoff of higher prices for a lower sales quantity could result in improved profitability at our research site. Our analysis discussed at the end of the last section suggests that

\footnotetext{
${ }^{5}$ Without detailed cost information it is not possible to ascertain if a reduction in revenues would result in lower profits. We don't know how franchisees may adjust costs once they obtain the property. If costs remained constant upon conversion, we estimate that if variable costs per room night were above a certain amount, say $\$ 15$ (disguised), the franchisee would be increasing total contribution margin by trading off the price gain of $\$ 2.66$ for a drop in occupancy of 5.5 percentage points. All of our analysis suggests this chain's variable cost is much lower the $\$ 15$ (disguised) amount, suggesting it is very likely there is drop in total contribution margin upon conversion resulting from the changes in revenue components.
} 
the firm's variable cost would have to be much higher than we estimate it to be to justify the revenue tradeoff documented here. However, other cost reductions are possible that would have led to improved financial performance. Another concern is the length of the estimation period. We believe two years is a long enough period to document changes, but if the franchisee is learning during this period, perhaps a longer window is needed. Finally, it would be useful to document predictors of cross-sectional differences in performance changes. While this study documents strong, persistent impacts for the converted units, franchising considerations may interact with other market and operating characteristics to drive cross-sectional differences. 


\section{References}

American Hotel \& Lodging Association (2006). The Uniform System of Accounts for the Lodging Industry. Washington, D.C.: American Hotel \& Lodging Association.

Banker, R. D., Potter, G., \& Srinivasan, D. (2000). An Empirical Investigation of an Incentive Plan that Includes Non-Financial Performance Measures. The Accounting Review, 75, 65-92.

Bradach, J. L. (1997). Using the Plural Form in the Management of Restaurant Chains. Administrative Science Quarterly, 42, 276-303.

Brickley, J.A., \& Dark, F. H. (1987). The Choice of Organization Form. The Case of Franchising. Journal of Financial Economics, 18, 401-420.

Campbell, D., Datar, S. M., \& Sandino, T. (2009). Organizational Design and Control Across Multiple Markets: The Case of Franchising in the Convenience Store Industry. Accounting Review, 84: 1749-1780.

Caves, R. E., \& Murphy, W. F. (1976). Franchising: Firms, Markets, and Intangible Assets. Southern Economic Journal, 42, 572-586.

Greene W.H. 1994. Econometric Analysis. New York, NY: Macmillan.

Gretzel, U., and K.-H. Yoo. 2008. Use and Impact of Online Travel Reviews. In Information Information and communication technologies in tourism, ed. P. O'Conner, W. Hopken, and U. Gretzel, 27058. Vienna, Austria: Springer.

Ittner, C., and Larcker, D. 1998. Innovations in performance measurement: Trends and research implications. Journal of Managerial Accounting Research: 205-238.

Kaplan, R. S., \& Norton, D. (1992). The Balanced-Scorecard: Measures that Drive Performance. Harvard Business Review (January-February), 71-79.

Keaveney, S.M. (1995). Customer switching behavior in service industries: An exploratory study. Journal of Marketing (April): 71-82.

Krueger, A. B. (1991). Ownership, Agency, and Wages: An Examination of Franchising in the Fast Food Industry. Quarterly Journal of Economics, 106: 75-101.

Lafontaine, F. (1992). Agency Theory and Franchising: Some Empirical Results. The Rand Journal of Economics, 23(2), 263-283.

Lafontaine, F. (1999). Franchising vs. Corporate Ownership: The Effect on Price Dispersion. Journal of Business Venturing, 14: 17-34.

Lafontaine, F., \& Slade, M. E. (1997). Retail Contracting: Theory and Practice. Journal of Industrial Economics, 45: 1-25.

Lafontaine, F., \& Slade, M. E. (2007). Vertical Integration and Firm Boundaries: The Evidence. Journal of Economic Literature, 45: 629-685.

Melian-Gonzalez, S. J. Bulchangd-Gidumal, and B. Gonzalez Lopez-Valcarcel. 2013. Online Customer Reviews of Hotels: As Participation Increases, Better Evaluation is Obtained." Cornell Hospitality Quarterly, 54(3): 274-283. 
Michael, S. C. (2000). The effect of organizational form on quality: The case of franchising. Journal of Economic Behavior and Organization, 43: 295-318.

Milgrom, P., \& Roberts, J. (1992). Economics, Organization and Management. Englewood Cliffs, NJ: Prentice Hall.

Moers, F. (2006). Performance Measure Properties and Delegation. The Accounting Review, 81(4), 897-924.

Ong, B.S. 2012. The Perceived Influence of User Reviews in the Hospitality Industry. Journal of Hospitality Marketing \& Management, 21(5): 463-485.

Noone, B., \& Griffin, P. (1999). Managing the Long-Term Profit Yield from Market Segments in a Hotel Environment: A Case Study on the Implementation of Customer Profitability Analysis. International Journal of Hospitality Management, 18, 111-128.

Norton, S. W. (1988). An Empirical Look at Franchising as an Organizational Form. Journal of Business, 61, 197-217.

Park, R.E. and B.M. Mitchell. (1980). Estimating the Autocorrelated Error Model with Trended Data. Journal of Econometrics 13: 185-201.

Prais, S.J. and C.B. Winsten. (1954). Trend Estimators and Serial Correlation, Cowels Commission discussion paper no. 383 (Chicago, IL).

Prendergast, C. (2002). The Tenuous Trade-off Between Risk and Incentives. Journal of Political Economy, 110, 1071-1102.

Raith, M. (2008). Specific Knowledge and Performance Measurement. The Rand Journal of Economics, 39(4), 1059-1079.

Shelton, J.P. (1967). Allocative Efficiency vs. "X-Efficiency": Comment. The American Economic Review, 57(5), 1252-1258.

Shepard, A. (1993), Contractual Form, Retail Price, and Asset Characteristics in Gasoline Retailing. Rand Journal of Economics 24:58-77.

Sorenson, O., \& Sørensen, J. B. 2001. Finding the Right Mix: Franchising, Organizational Learning, and Chain Performance. Strategic Management Journal, 22: 713-724.

Thomadsen, R. (2005). The Effect of Ownership Structure on Prices in Geographically Differentiated Industries. The RAND Journal of Economics, 36(4), 908-929.

Van der Meer-Kooistra, J. and E.G.J. 2006. Vosselman. Research on Management Control of Interfirm Transactional Relationships: Whence and Whither. Management Accounting Research, 17: 227-237.

Ye, Q., R. Law, and B. Gu. 2009. The Impact of Online User Reviews on Hotel Room Sales. International Journal of Hospitality Management, 28: 180-182.

Yin, X., and Zajac, E. J. (2004). The Strategy/Governance Structure Fit Relationship: Theory and Evidence in Franchising Arrangements. Strategic Management Journal, 25: 365-383. 
Table 1

Year of Conversion from Company Owned and Operated to Franchisee Control

\begin{tabular}{||l|c|c|c|c|c|c||}
\hline & \multicolumn{7}{|c|}{ Conversion Year } \\
\cline { 2 - 7 } & $\mathbf{2 0 0 6}$ & $\mathbf{2 0 0 7}$ & $\mathbf{2 0 0 8}$ & $\mathbf{2 0 0 9}$ & $\mathbf{2 0 1 0}$ & $\mathbf{2 0 1 1}$ \\
\hline Number of Units $(\mathrm{n}=56)$ & 5 & 5 & 14 & 14 & 14 & 4 \\
\hline
\end{tabular}


Table 2

\section{Descriptive Statistics of Key Variables in Study}

\begin{tabular}{||l|c|c|c|c|c|c||}
\hline \multicolumn{1}{|c|}{ Variable } & $\mathbf{N}$ & Mean & $\begin{array}{c}\text { Standard } \\
\text { Deviation }\end{array}$ & $\begin{array}{c}\text { First } \\
\text { Quartile }\end{array}$ & Median & $\begin{array}{c}\text { Third } \\
\text { Quartile }\end{array}$ \\
\hline \hline REVENUE & 2598 & 19.77 & 5.58 & 15.74 & 19.23 & 23.16 \\
\hline AVGRATE & 2598 & 37.36 & 4.31 & 34.58 & 37.10 & 39.68 \\
\hline OCCRATE & 2598 & 0.53 & 0.13 & 0.44 & 0.52 & 0.62 \\
\hline COMPLNTS & 2598 & 1.05 & 1.08 & 0.00 & 0.75 & 1.52 \\
\hline COMPREV & 2598 & 27.28 & 9.77 & 20.22 & 25.68 & 33.21 \\
\hline CAVGRATE & 2598 & 53.87 & 9.39 & 47.14 & 53.37 & 60.32 \\
\hline COCCRATE & 2598 & 0.50 & 0.13 & 0.41 & 0.50 & 0.59 \\
\hline
\end{tabular}

All numbers are disguised by multiplying by a scalar

REVENUE

AVGRATE

OCCRATE

COMPLNTS

COMPREV

CAVGRATE

COCCRATE
$=$ Revenue per available room of a property,

$=$ Average rate for a property measured as total revenues divided by number of occupied rooms in a month,

$=$ Occupancy rate for a property measured as number of occupied rooms divided by number of available rooms in a month,

$=$ Number of complaints per thousand guests for a property in a month,

$=$ Average revenue per available room of competitors of a property in a month,

$=$ Average rate of competitors of a property in a month,

$=$ Average occupancy rate of competitors of a property in a month. 


\section{Table 3}

Plots of Monthly Unexpected Performance for the 56 Properties Converted to Franchises in Event Time [Conversion Month $=0$ ]

(standardized prediction residuals)

Figure 1: Unexpected Revenue per Available Rooms (REVENUE)

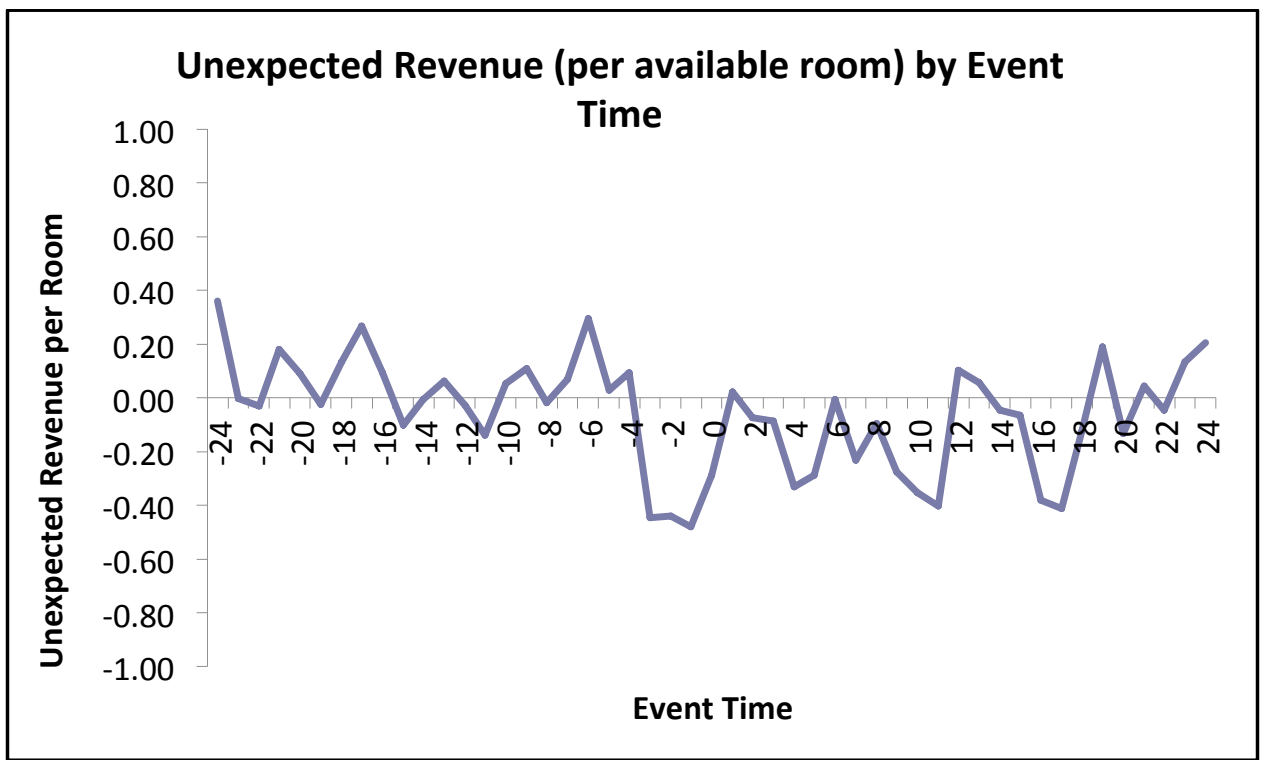

Figure 2: Unexpected Average Daily Room Rate (AVGRATE)

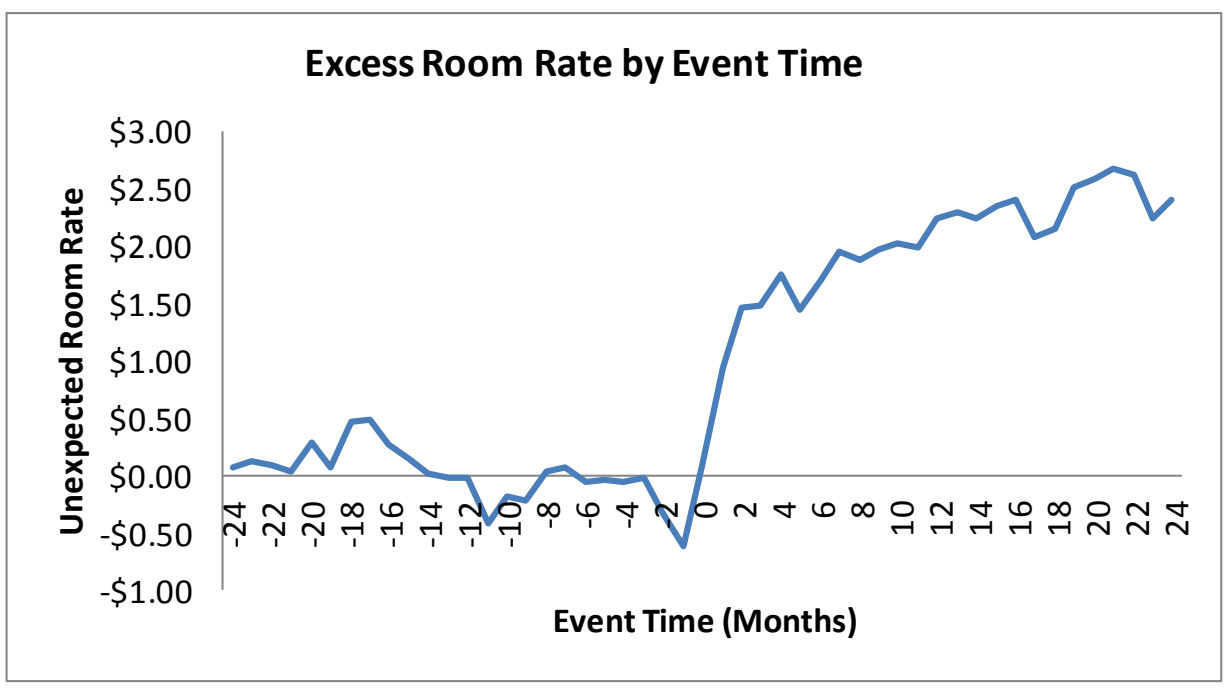


Table 3 (continued)

Figure 3: Unexpected Occupancy Rate (OCCRATE)

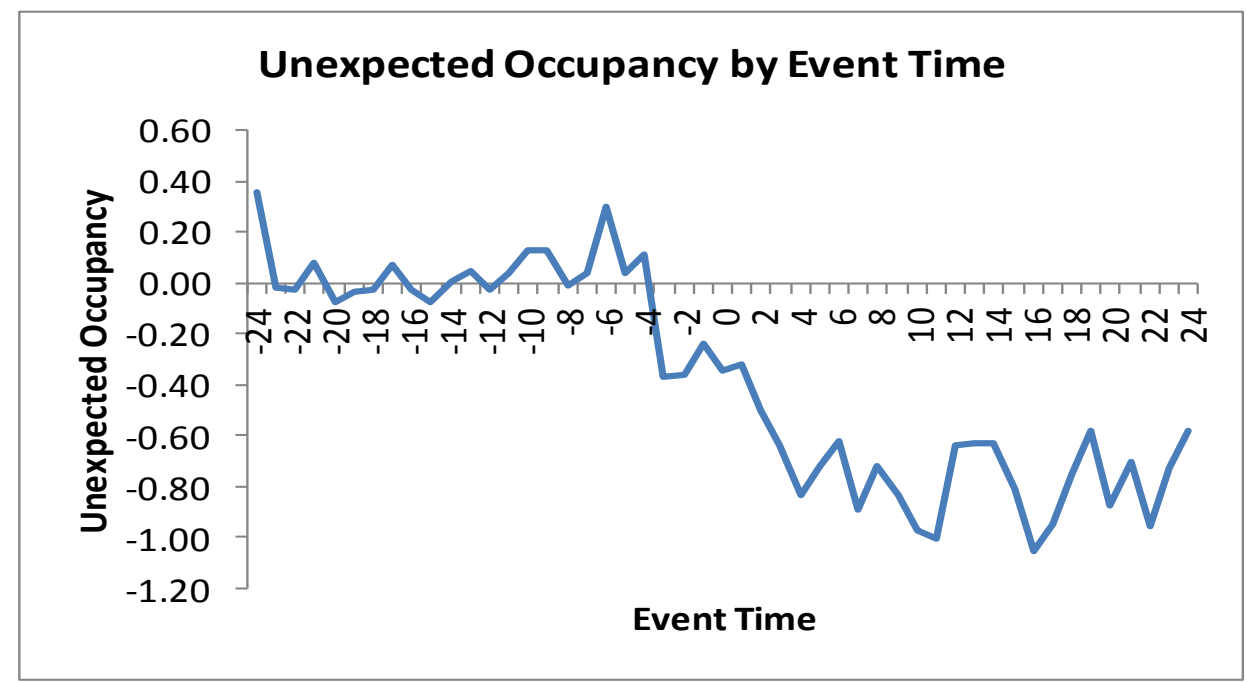

Figure 4: Unexpected Complaints (COMPLNTS)

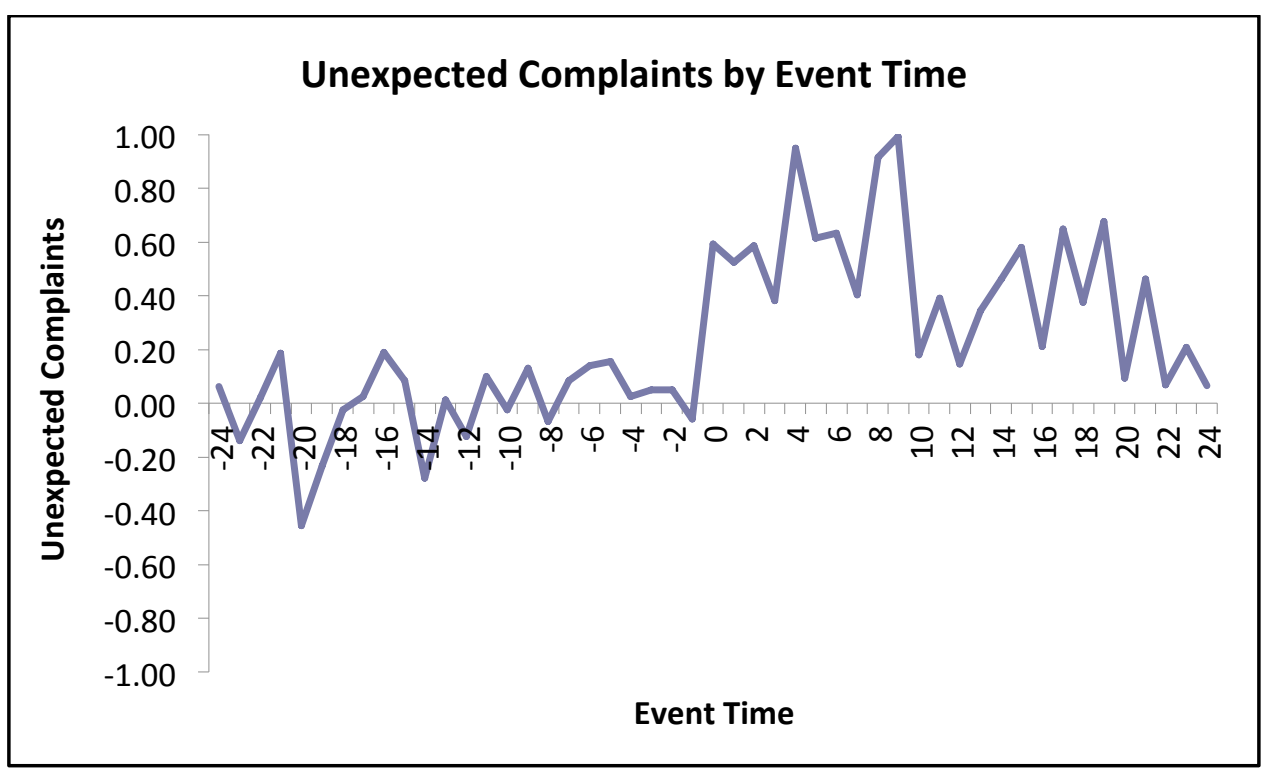


Table 3

Estimated Impacts of Franchise Conversion on Performance

( $\mathrm{t}$ statistics in parentheses)

$$
\begin{aligned}
& \text { AVGRATE }_{i t} \quad=\alpha_{0}{ }^{\mathrm{A}}+\sum_{\mathrm{i}=1}^{55} \beta_{\mathrm{i}}^{\mathrm{A}} \text { PROPERTY }_{\mathrm{i}}+\sum_{\mathrm{i}=1}^{56} \gamma_{\mathrm{i}}^{\mathrm{A}} \text { PROPERTY }_{\mathrm{i} A V G R A T E}+\sum_{\mathrm{q}=2}^{4} \gamma_{\mathrm{q}}{ }^{\mathrm{A}} \mathrm{D}_{\mathrm{q}} \\
& +\lambda_{1}{ }^{\mathrm{A}} \text { FRANCHISE }_{\mathrm{i}, \mathrm{t}}+\lambda_{2}{ }^{\mathrm{A}} \text { FRANCHISE } 2_{\mathrm{i}, \mathrm{t}}+\varepsilon_{\mathrm{it}}{ }^{\mathrm{A}} \\
& \text { OCCRATE }_{i t} \quad=\alpha_{0}{ }^{\mathrm{O}}+\sum_{\mathrm{i}=1}^{55} \beta_{\mathrm{i}}^{\mathrm{O}} \text { PROPERTY }_{\mathrm{i}}+\sum_{\mathrm{i}=1}^{56} \gamma_{\mathrm{i}}^{\mathrm{O}} \text { PROPERTY }_{\mathrm{i}} \text { COCCRATE }_{\mathrm{it}}+\sum_{\mathrm{q}=2}^{4} \gamma_{\mathrm{q}}^{\mathrm{o}} \mathrm{D}_{\mathrm{q}} \\
& +\lambda_{1}{ }^{\mathrm{O}} \text { FRANCHISE }_{\mathrm{i}, \mathrm{t}}+\lambda_{2}{ }^{\mathrm{O}} \text { FRANCHISE } 2_{\mathrm{i}, \mathrm{t}}+\varepsilon_{\mathrm{it}}{ }^{\mathrm{O}} \\
& \text { REVENUE }_{\mathrm{it}} \quad=\alpha_{0}{ }^{\mathrm{R}}+\sum_{\mathrm{i}=1}^{55} \beta_{\mathrm{i}}^{\mathrm{R}} \text { PROPERTY }_{\mathrm{i}}+\sum_{\mathrm{i}=1}^{56} \gamma_{\mathrm{i}}^{\mathrm{R}} \text { PROPERTY }_{\mathrm{i}} \text { COMPREV }_{\mathrm{it}}+\sum_{\mathrm{q}=2}^{4} \gamma_{\mathrm{q}}^{\mathrm{R}} \mathrm{D}_{\mathrm{q}} \\
& +\lambda_{1}^{\mathrm{R}} \text { FRANCHISE } \mathrm{i}_{\mathrm{i}, \mathrm{t}}+\lambda_{2}^{\mathrm{R}} \text { FRANCHISE } 2_{\mathrm{i}, \mathrm{t}}+\varepsilon_{\mathrm{it}}^{\mathrm{R}} \\
& \text { COMPLNTS }_{\text {it }} \quad=\alpha_{0}{ }^{\mathrm{C}}+\sum_{\mathrm{i}=1}^{55} \beta_{\mathrm{i}}^{\mathrm{C}} \text { PROPERTY }_{\mathrm{i}}+\sum_{\mathrm{i}=1}^{56} \gamma_{\mathrm{i}}{ }^{\mathrm{C}} \text { PROPERTY }_{\mathrm{i}} \mathrm{CCOMPLNTS}_{\mathrm{it}}+\sum_{\mathrm{q}=2}^{4} \gamma_{\mathrm{q}}{ }^{\mathrm{C}} \mathrm{D}_{\mathrm{q}} \\
& +\lambda_{1}{ }^{\mathrm{C}} \text { FRANCHISE }_{\mathrm{i}, \mathrm{t}}+\lambda_{2}{ }^{\mathrm{C}} \text { FRANCHISE } 2_{\mathrm{i}, \mathrm{t}}+\varepsilon_{\mathrm{it}}{ }^{\mathrm{C}}
\end{aligned}
$$

\begin{tabular}{|c|c|c|c|c|}
\hline Variable & AVGRATE & בCCRATE & REVENUE & COMPLNTS \\
\hline$\overline{\overline{\text { QTR }_{2}}}$ & $\begin{array}{c}1.893 * * * \\
(8.93)\end{array}$ & $\begin{array}{c}0.022 * * * \\
(2.96)\end{array}$ & $\begin{array}{c}1.502 * * * \\
(5.75) \\
\end{array}$ & $\begin{array}{c}0.137 * * \\
(2.22) \\
\end{array}$ \\
\hline $\mathrm{QTR}_{3}$ & $\begin{array}{c}1.749 * * * \\
(8.12)\end{array}$ & $\begin{array}{c}0.032 * * * \\
(4.18)\end{array}$ & $\begin{array}{c}1.896^{* * *} \\
(7.12)\end{array}$ & $\begin{array}{c}0.221^{* * *} \\
(2.74)\end{array}$ \\
\hline $\mathrm{QTR}_{4}$ & $\begin{array}{c}1.114^{* * *} \\
(5.41)\end{array}$ & $\begin{array}{l}0.002 \\
(0.25) \\
\end{array}$ & $\begin{array}{c}0.425^{*} \\
(1.69) \\
\end{array}$ & $\begin{array}{c}0.131^{* *} \\
(2.23)\end{array}$ \\
\hline FRANCHISE & $\begin{array}{c}2.230 * * * \\
(11.83)\end{array}$ & $\begin{array}{c}-0.056 * * * \\
(-8.86)\end{array}$ & $\begin{array}{c}-0.863 * * * \\
(-3.79)\end{array}$ & $\begin{array}{c}0.384 * * * \\
(7.40)\end{array}$ \\
\hline FRANCHISE2 & $\begin{array}{c}0.434^{* *} \\
(2.02) \\
\end{array}$ & $\begin{array}{l}-0.001 \\
(-0.16) \\
\end{array}$ & $\begin{array}{l}0.158 \\
(0.61) \\
\end{array}$ & $\begin{array}{c}-0.212^{* * *} \\
(-3.59) \\
\end{array}$ \\
\hline$\overline{\mathrm{R}^{2}}$ & 0.9491 & 0.7826 & 0.8169 & 0.2337 \\
\hline $\mathrm{P}$ (model) & 0.0001 & 0.0001 & 0.0001 & 0.0001 \\
\hline & & & & \\
\hline $\mathrm{P}\left(\lambda_{1}+\lambda_{2}=0\right)$ & 0.0001 & 0.0001 & 0.0022 & 0.0010 \\
\hline & & & & \\
\hline $\mathrm{N}$ & 2597 & 2598 & 2598 & 2598 \\
\hline
\end{tabular}

$*, * *$ and $* * *$ indicate that the estimated coefficient is significantly different from zero at the $10 \%, 5 \%$ and $1 \%$ levels (two-tailed test), respectively.

PROPERTY $_{i}=$ A dummy variable $=1$ if PROPERTY $i,=0$ otherwise.

$\mathrm{D}_{\mathrm{q}}=$ Indicator variable for quarters $\mathrm{q}$.

FRANCHISE $=$ indicator variable that equals one upon conversion, otherwise zero.

FRANCHISE2 $=$ indicator variable that equals one 12 months after conversion, otherwise zero.

CCOMPLNTS $=$ monthly average complaints per thousand rooms for company's owned properties.

See Table 2 for all other definitions. 